\title{
Effect of including herbal choline in the diet of a dairy herd; a multiyear evaluation
}

\author{
Alfredo Gutiérrez R' ${ }^{1}$, Alfredo Gutiérrez ${ }^{1}$, Carlos Sánchez², Germán D. Mendoza ${ }^{3 *}$ \\ ${ }^{1}$ Granja el Tepeyac, Circuito Jade 138, Pachuca de Soto- Hidalgo- México- CP 42084, ${ }^{2}$ Nuproxa México, Sendero del mirador 36 - \\ Querétaro- México CP 7606, ${ }^{3}$ Universidad Autónoma Metropolitana Xochimilco, Calz. del Hueso 1100 - México City - México CP 04960
}

\section{A B S T R A C T}

\begin{abstract}
A linear mixed model and chi-squared tests were used to estimate the effects of the dietary inclusion of herbal choline at $0.071 \%$ of the diet in the entire dairy herd (target dose of $17 \mathrm{~g} / \mathrm{d}$ in lactating cows) using data from six years in a commercial farm. The feed plant additive (BioCholine) was included in the premix spanning three years (2016-2018) feeding 442 cows average per year and information was compared with the three previous years (2013 - 2015; 424 cows average per year). Energy corrected milk in the period 2016-2018 was increased by $1.57 \%(p<0.001)$ compared to years $2013-2016(36.36$ vs. $35.80 \mathrm{~kg} / \mathrm{d})$. Fertility in cows during first lactation was improved $(\mathrm{P}<0.01)$ with the feed plant additive $(45.33$ vs. $37.0 \%)$. The period feeding herbal choline $(2016-2018)$ showed a reduction $(p<0.0001)$ in abortions $(15.65$ to $7.29 \%)$ and clinical $(p<0.005 ; 12.59$ to $6.95 \%)$ and subclinical mastitis $(p<0.05 ; 8.65$ to $5.22 \%)$ and in respiratory disorders ( $p<0.10 ; 12.42$ to $8.56 \%$ ) whereas hypocalcaemia incidence was increased $(p<0.01$ ) from 1.73 to $6.22 \%$. Total herd replacement was reduced during the years $2016-2018$ by $5.73 \%(p<0.05)$ without effects in mortality. Inclusion of the plant feed additives containing conjugates of choline improved milk yield, fertility in first lactation cows and important health indicators which help to reduced herd replacement.
\end{abstract}

Keywords: Dairy cow; Choline; Feed plant additive; Multiyear evaluation

\section{INTRODUCTION}

Despite the statistical problem of pseudoreplication, multiyear comparison studies have been conducted in dairy cattle to evaluate genetic advances with dietary interactions in fertility and longevity (Harris and Kolver, 2001), long-term grazing assessments (Coffey et al., 2018), and to assess the impact of technology transfer in dairy cattle in tropics (Cárdenas-Bejarano et al., 2016) and is an alternative to provide more information than that obtained in experimental conditions over short time periods.

Choline is a nutrient that can have a great impact in production and health of dairy cattle, yet its requirements have not been precisely defined (NRC, 2001). Experiments with ruminally protected choline (RPC) have shown that milk production and health of dairy cattle can be improved and the incidence of fatty liver problems reduced when $\mathrm{RPC}$ is provided during late transition and early postpartum periods (Piepenbrink and Overton, 2003, Pinotti et al.,
2003, Lima et al., 2012). Despite the scientific evidence compiled in several reviews (Pinotti et al., 2010; Sales et al., 2010; Jayaprakash et al., 2017), RPC is not included in many milk production units because the relative profitability appears small when analyzed solely from milk yield without considering other long-term benefits from its inclusion. There is one plant feed additive containing phosphatidylcholine with the potential to replace RCP products that shows natural resistance to ruminal degradation in sheep studies (Godinez-Cruz et al., 2015; Crosby et al., 2017) and with greater profitability than the choline chloride products. The herbal product contains Achyrantes Aspera, Trachyspermum ammi, Azadirachta Indica, Citrullus Colocynthis and Andrographis paniculata and has been evaluated in dairy cattle with positive responses in milk production (Mendoza et al., 2019; Cañada et al., 2018). It is known that some of the plants reported in the phytogenic additive have a wide range of antimicrobial and antioxidant activities through secondary metabolites which stimulate the immune system (Upadhaya and Kim, 2015; Frankič

\footnotetext{
*Corresponding author:

Germán D. Mendoza, Universidad Autónoma Metropolitana Xochimilco, Calz. del Hueso 1100 - México City - México CP 04960.

E-mail: gmendoza@correo.xoc.uam.mx

Received: 01 March 2019; $\quad$ Accepted: 12 June 2019
} 
et al, 2009). Some of the plants reported in the herbal product contains volatile metabolites such as 2 -Undecenal, 8-p-menthane diamine, 4-vinylguaiacol, $\beta$-pinene, $\mathrm{p}$-cresol (Mendoza et al., 2019) some aldehydes with bacteriostatic and bactericidal effects (Widhalm et al., 2016; Esatbeyoglu et al., 2015; Zhu et al., 2017). Therefore, a multi-year study was conducted to evaluate the incorporation of an herbal product to provide dietary choline to an entire dairy herd for three years, comparing production, health and replacements data with the average of the three previous years, maintaining the same management practices.

\section{MATERIAL AND METHODS}

\section{Experimental data}

The study was conducted at the commercial dairy herd El Tepeyac Hidalgo, Mexico (20 13 ' 29" N, $99^{\circ} 02^{\prime} 52$ ” W, $2000 \mathrm{~m}$ above sea level) with annual mean temperature of 15.64 ${ }^{\circ} \mathrm{C}$ (hottest $25.67^{\circ} \mathrm{C}$ and coldest $7.21^{\circ} \mathrm{C}$ average respectively). Data from six years were used to compare the inclusion of BioCholine in the nuclei premix of the farm, comparing 2016-2018 (442 cows) versus the previous three-year period (2013 - 2015, 424 cows average per year; Table 1). The farms used a crossbreeding rotational program using Holstein x Montbeliarde x Swedish Red; using Holstein cows, using semen from Montbeliarde bulls; next generation semen from Swedish Red, the resulting generation is bred with semen from Holstein. Rations are formulated on NRC (2001) requirements for the different physiological stages based on ryegrass silage, corn silage, triticale silage, canola meal, soybean meal, corn grain, and a formulated premix including commercial sources of ruminally protected protein and inert fat, mineral and vitamins without ruminally protected choline. BioCholine is an herbal product made with plants native to India including Achyrantes Aspera, Trachyspermum ammi, Azadiracbta Indica, Citrullus Colocynthis and Andrographis paniculata. Since 2017 the feed plant additive BioCholine (Nuproxa, Mexico, Indian Herbs) was included in the premix at $0.071 \%$ of total mixed ration with a target intake of $17 \mathrm{~g} / \mathrm{d}$ of feed plant additive in cows consuming $24 \mathrm{~kg} / \mathrm{DM}$. Aside from normal variations in feed quality, diets over the years did not change significantly.

Milk production was recorded daily using an automatic equipment Afi-lite Plus which also records milk conductivity for the daily diagnosis of ketosis and mastitis (Antanaitis et al., 2015). Milk composition (fat, protein, lactose, total solids and non-fatty solids) and cell counts were measured in an automatic Foss Analyzer. Individual veterinary problems were analyzed from the database by cow per year and information on reproductive performance was obtained from the databases up to 365 days (Williams
Table 1: Multiyear comparison of energy corrected milk with or without herbal choline

\begin{tabular}{lccccc}
\hline Year & ECM & Min & Max & C.V. & $\begin{array}{c}\text { No. } \\
\text { cows }\end{array}$ \\
\hline 2013 & $35.11^{\mathrm{d}}$ & 33.05 & 38.95 & 2.83 & 422 \\
2014 & $36.31^{\mathrm{b}}$ & 33.70 & 39.09 & 2.86 & 423 \\
2015 & $36.01^{\mathrm{c}}$ & 32.36 & 39.63 & 3.72 & 427 \\
2016 & $36.84^{\mathrm{a}}$ & 33.23 & 38.98 & 2.82 & 433 \\
2017 & $36.11^{\mathrm{cb}}$ & 34.06 & 41.23 & 2.21 & 438 \\
2018 & $36.15^{\mathrm{cb}}$ & 35.38 & 41.23 & 3.18 & 457 \\
\hline
\end{tabular}

ECM: energy corrected milk; C.V.: coefficient of variation. abcMeans with different superscript differ $(p<0.05)$.

Table 2: Contrast comparison of milk yield among years with feed plant additive

\begin{tabular}{lcccc|}
\hline Milk yield & $2013-2015$ & 2015-2018 & SEM & $\begin{array}{c}\text { Contrast } \\
\text { p-value }\end{array}$ \\
\hline ECM kg/d & $35.80^{\mathrm{b}}$ & $36.36^{\mathrm{a}}$ & 0.056 & 0.0001 \\
FCM kg/d & $35.93^{\mathrm{b}}$ & $36.34^{\mathrm{a}}$ & 0.063 & 0.0001 \\
\hline
\end{tabular}

ECM: energy corrected milk; FCM: fat corrected milk; SEM: Standard error of the mean. abcMeans within row with different superscript differ $(p<0.0001)$.

et al., 2005). The variable selected to compare milk yield and quality was energy corrected milk (ECM) because it determines the amount of energy in the milk based upon milk, fat and protein (Reist et al., 2002), calculated as $\mathrm{ECM}=[(0.327 \bullet \mathrm{kg}$ milk $)+(12.95 \mathrm{~kg}$ fat $)+(7.2 \mathrm{~kg}$ protein)]; milk corrected fat was also calculated (Bertoni and Trevisi, 2013).

\section{Statistical analysis}

Milk yield was tested for normality and milk across years was compared with a linear mixed model (Coffey et al., 2018) with the following model: Yij $=\mu+\tau i+a j+$ eij, in which $\mu$ is the year-treatment mean value, $\tau i$ is the yeartreatment effect (fixed), aj is the effect of animal, and eij is the error term. Means by year were compared with a Tukey test and then a specific orthogonal contrast for milk yield average 2013-216 versus 2016-2018 was tested to evaluate the incorporation of the feed plant additive. Number of diseases and replacement data were expressed in percentage and tested using chi square test (Kim, 2017). Data were analyzed using the JMP7 software (Sall et al., 2012).

\section{RESULTS AND DISCUSSION}

Energy corrected milk showed a normal distribution (Shapiro-Wilk 0.998, p< 0.07) with a mean of $36.08 \pm$ $1.20 \mathrm{~kg} / \mathrm{d}$, median 36.09 and mode 35.20. The ECM comparison among years is presented in Table 1. The contrast used to test the inclusion of feed plant additive was significant $(\mathrm{p}<0.001)$ and $\mathrm{ECM}$ in $2016-2018$ was higher representing an increment of $1.57 \%$ and when comparison was done with energy corrected fat results were similar with an increment of $1.15 \%$ (Table 2). In multi- 
Table 3: Multiyear comparison of productive parameters (\%) with or without feed plant choline

\begin{tabular}{|c|c|c|c|c|c|c|}
\hline Parameter & 2013-2016 & 2017-2018 & Additive difference $\%$ & $95 \%$ confidence interval & Chi-squared & $p$-value \\
\hline \multicolumn{7}{|l|}{ Fertility (\%) } \\
\hline Overall & 35.00 & 37.33 & 2.33 & -4.0639 to 8.6866 & 0.508 & 0.47 \\
\hline $1^{\text {st }}$ lactation & 37.00 & 45.33 & 8.33 & 1.7719 to 14.7810 & 6.189 & 0.012 \\
\hline $2^{\text {nd }}$ lactation & 34.67 & 34.33 & -0.33 & -5.9675 to 6.6556 & 0.011 & 0.91 \\
\hline $3^{\text {rd }}$ lactation & 33.33 & 33.67 & 0.33 & -5.9355 to 6.5991 & 0.011 & 0.91 \\
\hline Multipars & 34.00 & 34.00 & 0.00 & -6.2960 to 6.2837 & 0.0 & 1.0 \\
\hline \multicolumn{7}{|l|}{ Diseases (\%) } \\
\hline Abortions & 15.65 & 7.29 & -8.36 & 4.1408 to 12.6580 & 14.976 & 0.0001 \\
\hline Lameness & 23.90 & 24.48 & 0.59 & -5.1301 to 6.2656 & 0.04 & 0.84 \\
\hline Digestive & 11.56 & 9.12 & -2.44 & -1.6344 to 6.5647 & 1.391 & 0.23 \\
\hline Hypocalcaemia & 1.73 & 6.22 & 4.49 & 1.9146 to 7.2816 & 11.290 & 0.0008 \\
\hline Clinical mastitis & 12.59 & 6.95 & -5.65 & 1.6900 to 9.6779 & 7.842 & 0.005 \\
\hline Subclinical-mastitis & 8.65 & 5.22 & -3.44 & 0.0307 to 6.9382 & 3.959 & 0.04 \\
\hline Metritis & 7.55 & 6.55 & -1.00 & -2.4531 to 4.5071 & 0.330 & 0.56 \\
\hline Respiratory & 12.42 & 8.56 & -3.87 & -0.2320 to 8.0124 & 3.442 & 0.06 \\
\hline Retained placent & 8.88 & 8.73 & -0.14 & -3.6615 to 3.9950 & 0.006 & 0.93 \\
\hline Replacement \% & 26.72 & 20.98 & -5.73 & 0.0640 to 11.3914 & 3.928 & 0.04 \\
\hline Mortality & 2.18 & 1.47 & -0.72 & -1.1964 to 2.7417 & 0.611 & 0.43 \\
\hline
\end{tabular}

year evaluations there are environmental factors, genetics merit or interactions that can affect the results (Coffey et al., 2018), but the rotational cross used in the farm is designed to maintain heterosis and milk production yield and quality. The number of animals in the heard (Table 1) reflected a minor replacement which in the multiyear study is reflecting an improvement in reproductive performance and health characteristics with low heritability (Donagh et al., 2011). The effects of the feed additive are clearly shown when comparing the contrasts of the years in milk (Table 2), where the changes are similar to those observed in controlled experiments with the same phytogenic (Mendoza et al., 2019). In another evaluation of the same herbal choline, Holstein cows received 15 grams/d for 90 days after calving and increased milk production by 3\% (Mendoza et al., 2019). The same herbal product was evaluated in different doses with Holstein, Jersey and cross cows (0,10 and 20 grams/cow/day) for 90 days (Cañada et al., 2018) showing a linear response in milk production (5\%). Evaluations with RPC products have improved milk yield from 7 to $8 \%$ over the control (Scheer et al., 2002, Jayaprakash et al., 2017) but there is a dose response (Pinotti et al., 2010, Sales et al., 2010). The polyherbal evaluated in this study is a standardized mixture of choline conjugates which have previously been shown capable of replacing synthetic RPC in lamb and ewe diets (Godinez-Cruz et al., 2105; Crosby et al., 2017).

Effects of herbal choline are shown in Table 3. Fertility in cows during first lactation was improved by $8.33 \%(\mathrm{p}<0.01)$ with the inclusion of the feed plant additive. Comparing health disorders in the periods 2013-2015 versus 2016-2018 it was observed there was a reduction $(\mathrm{p}<0.0001)$ of $4.8 \%$ in abortions, $5.45 \%$ reduction in clinical mastitis $(\mathrm{p}<0.005)$ and $3.44 \%$ reduction in subclinical mastitis $(\mathrm{p}<0.04)$; respiratory problems were also reduced $(\mathrm{p}<0.06)$ by $3.87 \%$. In contrast, hypocalcaemia incidence was increased $(\mathrm{p}<0.0001)$ by $9.75 \%$ while other problems were unaffected by inclusion of the feed plant additive. Total replacement percentage was reduced by $5.73 \%(\mathrm{p}<0.04)$ without effects in mortality. Most of the evaluations using rumen protected choline have been conducted using cows in the transition period and during the early lactation stage (Pinotti et al., 2010; Sun et al., 2016; Lima et al., 2012; Piepenbrink and Overton, 2003) and there are few experiments extending until 70 days postpartum (Ardalan et al., 2010; Davidson et al., 2008; Cañada et al., 2018). In commercial herds, the use of RPC is usually not extended throughout the entire lactation because of the costs of the products. The feed plant additive with choline allows its incorporation for extended periods to obtain the benefits of the nutrient and economical evaluations of RPC. Herbal choline supplemented to lambs feed indicated that herbal sources are more profitable (Lee et al., 2016).

The increase in hypocalcaemia cases (Table 3) may be due to the increase in milk production resulting from the inclusion of herbal choline. Higher milk yields have been accompanied by increasing metabolic problems and declining longevity and fertility (Oltenacu and Broom, 2010). However, in the case of choline the negative effects are compensated by improvement in the energetic status of the cows. Since replacements in the unit were reduced over two years and the fertility was not negatively affected, it would appear that the productive life of the cows was not negatively affected, and other diseases were reduced 
with supplementation of the plant additive choline. Choline supplementation with RPC sources have reduced ketosis problems and increased milk production (Baldi and Pinotti, 2006; Sales et al., 2016). Lima et al. (2012) reported that the energetic status of cows and morbidity in general are also improved and supplemental choline did not affect pregnancy rate as observed in this evaluation and others (Ardalan et al., 2009).

As observed in our study (Table 3), it has been demonstrated that supplementing bypass choline to cows before calving reduces mastitis problems and general morbidity (Lima et al., 2012). The reduction in replacements in the herd when fed the plant additive could be explained by improvements in health due to the metabolic functions of choline, particularly those that stimulate immune response (Lewis et al., 2016). Cows supplemented with RPC showed improved immunological functions (Sun et al., 2016, Vailati-Riboni et al., 2017). Choline is also part of the platelet activating factor (1-alkyl2-acetyl-sn-glycero-3-phosphocholine), a potent activator of immune response (Prescott et al., 2000). Choline has protective functions of the mitochondria, increases cellular antioxidant capacity, decreases triglycerides in liver cells, and promotes lipid catabolism and the elimination of radicals (Zhu et al., 2014). In addition, choline and its metabolites perform other functions, participating as a methyl donor and in the synthesis of acetylcholine and phosphatidylcholine (PCho) and phosphatidylserine (Finkelstein, 2000); PCho is the main phospholipid in cell membranes throughout the body ( $\mathrm{Li}$ and Vance, 2008), PCho participates in the synthesis and export of triglycerides in very low-density lipoproteins (VLDL) in the liver (Zeisel, 2006) and PCho is required for the synthesis of dipalmitoyl-phosphatidylcholine, the main active surfactant component on the surface of the lungs (Gutierrez et al., 2015). PCho is also a precursor of sphingomyelin (Tayebati et al., 2015). The dietary PCho stimulates formation of IL-2 and the expression of CD25, CD28, CD71 in the spleen (Lewis et al., 2016) improving the immune response.

A multiyear evaluation provided the opportunity to make global analyses assessing changes in milk yield, reductions in metabolic problems and other production diseases as well as fertility to evaluate the overall herd economic impact (Oltenacu and Broom, 2010). Losses due to clinical and subclinical mastitis are significant per cow per year (Hogeveen et al., 2011). It is important to consider that not all the positive responses observed in cows' health may be associated solely with choline but may be attributable to other metabolites from the feed plant additive. It could be due to the change in the genetic makeup, also.

\section{CONCLUSIONS}

The multiyear evaluation allowed to detect beneficial effects of choline inclusion from the feed plant additive improving milk yield and fertility in first lactation cows, reducing abortions, mastitis (clinical and subclinical), respiratory problems and reducing the need for herd replacements. However, hypocalcaemia disorders were increased, presumably associated with a higher yield. Overall evaluation indicates that the inclusion of the feed plant additives containing conjugates of choline at $0.071 \%$ of the diet is an alternative to improve dairy farm profitability.

\section{ACKNOWLEDGEMENT}

The authors thanks Ray Jones for the revision and contributions of the document.

\section{Author's contributions}

A. G. R. and A. G. I.: collected the data and supervised the research project. G. D. M. and C. S: designed the data analyses; G. D. M. and A. G. I. did the statistical analysis. All authors were involved in manuscript preparation.

\section{REFERENCES}

Antanaitis, R., V. Žilaitis, A. Kučinskas, V. Juozaitienè and K. Leonauskaitè. 2015. Changes in cow activity, milk yield, and milk conductivity before clinical diagnosis of ketosis, and acidosis. Vet. Med. Zoot. T. 70: 3-9.

Ardalan, M., K. Rezayazdi and M. Dehghan-Banadaky. 2009. Investigation on the effect of supplementing rumen-protected forms of methionine and choline on health situation and reproductive performance of Holstein dairy cows. Pak. J. Biol. Sci. 12: 69-73.

Baldi, A. and L. Pinotti. 2006. Choline metabolism in high-producing dairy cows: Metabolic and nutritional basis. Can. J. Anim. Sci. 86: 207-212.

Bertoni, G. and E. Trevisi. 2013. Use of the liver activity index and other metabolic variables in the assessment of metabolic health in dairy herds. Vet. Clin. North Am. Food. Anim. Pract. 29: 413-431.

Cañada, L. M. G., E. Meraz, G. D. Mendoza, B. V. Villagrán and M. D. A. Castillo. 2018. Efecto del nivel de colina herbal en la producción y composición de leche en ganado lechero en pastoreo. Arch. Latinoam. Prod. Anim. 26(Suppl 1): 82.

Cárdenas-Bejarano, E, F. Gallardo-López, J. F. Nuñez-Espinoza, A. Asiaín-Hoyos, M. A. Rodríguez-Chessani and L. G. VelázquezBeltrán. 2016. Redes de innovación en los grupos ganaderos de validación y transferencia de tecnología en México. Agric. Soc. Desarro. 13: 237-255.

Coffey, E. L, L. Delaby, C. Fleming, K. M. Pierce, and B. Horan. 2018. Multi-year evaluation of stocking rate and animal genotype on milk production per hectare within intensive pasture-based production systems. J. Dairy Sci. 101: 2448-2462.

Crosby, M., G. D. Mendoza-Martinez, A. Relling, V. A. Vazquez, H. A. 
Lee-Rangel, J. A. Martinez and M. Oviedo. 2017. Influence of supplemental choline on milk yield, fatty acid profile, and postpartum weight changes in suckling ewes. J. Dairy Sci. 100(Suppl 2): 125.

Davidson, S., B. A. Hopkins, J. Odle, C. Brownie, V. Fellner and L. W. Whitlow. 2008. Supplementing limited methionine diets with rumen-protected methionine, betaine, and choline in early lactation Holstein cows. J. Dairy Sci. 91: 1552-1559.

Donagh, P. B., M. L Bermingham, M. Good, and S. J. More. 2011. Genetics of animal health and disease in cattle. Ir. Vet. J. 64:5-15.

Esatbeyoglu, T., K. Ulbrich, C. Rehberg, S. Rohn and G. Rimbach. 2015. Thermal stability, antioxidant, and anti-inflammatory activity of curcumin and its degradation product 4-vinyl guaiacol. Food Funct. 6: 887-893.

Finkelstein, J. D. 2000. Pathways and regulation of homocysteine metabolism in mammals. Semin. Thromb. Hemost. 26: 219-225.

Frankič, T., M. Voljč, J. Salobir, and V. Rezar. 2009. Use of herbs and spices and their extracts in animal nutrition. Acta Agric. Slov. 94: 95-102.

Godinez-Cruz, J., O. Cifuentes-López, J. Cayetano,H.A.Lee-Rangel, G. Mendoza, A. Vázquez and A. Roque. 2015. Effect of choline inclusion on lamb performance and meat characteristics. J. Anim. Sci. 93(Suppl 3): 766.

Gutierrez, D. B., A. Fahlman, M. Gardner, D. Kleinhenz, M. Piscitelli, S. Raverty, M. Haulena and P. V. Zimba. 2015. Phosphatidylcholine composition of pulmonary surfactant from terrestrial and marine diving mammals. Respir. Physiol. Neurobiol. 211: 29-36.

Harris, B. L. and E. S. Kolver. 2001. Review of holsteinization on intensive pastoral dairy farming in New Zealand. J. Dairy Sci. 84: E56-E61.

Hogeveen, H., K. Huijps and T. J. Lam. 2011. Economic aspects of mastitis: New developments. N. Z. Vet. J. 59: 6-23.

Jayaprakash, G., M. Sathiyabarathi, M. A. Robert and T. Tamilmani. 2016. Rumen-protected choline: A significance effect on dairy cattle nutrition. Vet. World. 9: 837-841.

Kim, H. Y. 2017. Statistical notes for clinical researchers: Chi-squared test and fisher's exact test. Restor. Dent. Endod. 42: 152-155.

Lewis, E. D., C. Richard, S. Goruk, N. S. Dellschaft, J. M. Curtis, R. L. Jacobs and C. J. Field. 2016. The form of choline in the maternal diet affects immune development in suckled rat offspring. J. Nutr. 146: 823-830.

Li, Z. and D. E. Vance. 2008. Thematic review series: Glycerolipids. Phosphatidylcholine and choline homeostasis. J. Lipid Res. 49: 1187-1194.

Lima, F. S., M. F. Sá Filho, L. F. Greco and J E. P. Santos. 2012. Effects of feeding rumen-protected choline on incidence of diseases and reproduction of dairy cows. Vet. J. 193: 140-145.

Mendoza, G. D., M. F. Oviedo, J. M. Pinos, H. A. Lee-Rangel, A. Vázquez, R. Flores, F. Pérez. 2019. Milk production in dairy cows supplemented with herbal choline and methionine. Rev. Fac. Cien. Agrarias. 1(1): 1-12.

NRC. 2001. Nutrient Requirements of Dairy Cattle. $7^{\text {th }}$ ed. The National Academic Press, Washington, DC.

Oltenacu, P. A. and D. M Broom. 2010. The impact of genetic selection for increased milk yield on the welfare of dairy cows. Anim. Welf. 19: 39-49.
Piepenbrink, M. S. and T. R. Overton. 2003. Liver metabolism and production of cows fed increasing amounts of rumen protected choline during the periparturient period. J. Dairy Sci. 86: 17221733.

Pinotti, L., C. Polidori, A. Campagnoli, V. Dell'Orto and A. Baldi. 2010. A meta-analysis of the effects of rumen protected choline supplementation on milk production in dairy cows. EAAP Sci. Ser. 127: 321-322.

Reist, M., D. Erdin, D. von Euw, K. Tschuemperlin, H. Leuenberger, Y. Chilliard, H. N. Hammon, C. Morel, C. Philipona, Y. Zbinden, N. Kuenzi and J. W. Blum. 2002. Estimation of energy balance at the individual and herd level using blood and milk traits in highyielding dairy cows. J. Dairy Sci. 85: 3314-3327.

Sales, J., P. Homolka and V. Koukolova. 2010. Effect of dietary rumen-protected choline on milk production of dairy cows: A meta-analysis. J. Dairy Sci. 93: 3746-3754.

Sall, J., A. Lehman, M. Stephens and L. Creighton. 2012. JMP Start Statistics: A Guide to Statistics and Data Analysis. SAS Institute Inc, Cary, NC, USA.

Scheer, W. A., M. C. Lucy, M. S. Kerley and J. N. Spain. 2002. Effects of feeding soybeans and rumen-protected choline during late gestation and early lactation on performance of dairy cows. J. Dairy Sci. 85(Suppl 1): 276.

Sun, F., Y. Cao, C. Cai, S. Li, C. Yu and J. Yao. 2016. Regulation of nutritional metabolism in transition dairy cows: Energy homeostasis and health in response to post-ruminal choline and methionine. PLoS One. 11: e160659.

Tayebati, S. K., G. Marucci, C. Santinelli, M. Buccioni and F. Amenta. 2015. Choline-containing phospholipids: Structure-activity relationships versus therapeutic applications. Curr. Med. Chem. 22: 4328-4340.

Upadhaya, S. and I. H. Kim. 2015. Efficacy of phytogenic feed additive on performance, production and health status of monogastric animals a review. Ann. Anim. Sci. 17: 929-948.

Vailati-Riboni, M., Z. Zhou, C. B. Jacometo, A. Minuti, E. Trevisi, D. N. Luchini and J. J. Loor. 2017. Supplementation with rumenprotected methionine or choline during the transition period influences whole-blood immune response in periparturient dairy cows. J. Dairy Sci. 100: 3958-3968.

Widhalm, B., T. Ters, E. Srebotnik and C. Rieder-Gradinger. 2016. Reduction of aldehydes and terpenes within pine wood by microbial activity. Holzforschung. 70: 895-900.

Williams, E. J., D. P. Fischer, D. V. Pfeiffer, G. C. Englang, D. E. Noakes, H. Dobson and I. M. Sheldon. 2005. Clinical evaluation of postpartum vaginal mucus reflects uterine bacterial infection and the immune response in cattle. Theriogenology. 63: 102-111.

Zeisel, S. H. 2006. Choline: Critical role during fetal development and dietary requirements in adults. Annu. Rev. Nutr. 26: 229-250.

Zhu, J., Y. Wu, Q. Tang, Y. Leng and W. Cai. 2014. The effects of choline on hepatic lipid metabolism, mitochondrial function and antioxidative status in human hepatic C3A cells exposed to excessive energy substrates. Nutrients. 6: 2552-2571.

Zhu, S., X. Yang, S. Xu, Z. Zhao and J. Jiang. 2017. Synthesis and antibacterial activity of bis-alkanoyl-amines heterocyclic derivatives of cis-1, 8-p-Menthane Diamine. Chem. Ind. Forest. Prod. 37: 79-84. 